stock. She has been working recently at the Royal (Dick) Veterinary College, Edinburgh, where she has been very greatly helped and whence she has sent us the following note on the Exmoor Pony by Professor T. Grahame of the Department of Anatomy.

"It seems probable that the Exmoor Pony is the living representative of a prehistoric horse which formerly roamed Britain, and this probability is strengthened by the similarity which exists between the skeletal material of authentic specimens of the breed, and fossils and bones which have been collected in the department of anatomy at the College.

"This work is being carried through under difficulties as very little time and money are available, but it has been undertaken on account of the interesting possibilities the material presents.

"The Exmoor Pony shows distinct features that distinguish it from all other breeds and these features appear to have survived from the European primitive horse stock.

"It is evident from the fauna that inhabits Exmoor to-day that it has possibly been retained in this isolated area from very early times.

"There are certain characteristics found in the sheep, cattle, and ponies which are particular to these animals."

\title{
THE WALRUS
}

By Colin Matheson, M.A., B.Sc.

(National Museum of Wales.)

The Walrus is confined to the northern circumpolar regions, its range northward apparently extending to the limit of perpetual ice. Now rare in Iceland, Odobenus rosmarus is stated to be still not unfamiliar in Hudson Bay, Davis Strait, and Baffin Bay north to Ellesmere Land, the coasts of Greenland, Spitsbergen, Noviaia Zemlia, and the western part of the north coast of Sibcria; in all of which regions, however, persecution has greatly diminished its numbers. The species does not extend along the far eastern part of the north Siberian coast, and Walrus are not met with again until the north-eastern extremity of Siberia 
is reached. Here the Pacific Walrus, which differs somewhat from that of the Atlantic side and is regarded as a distinct species, Odobenus obesus, is reported from Cape Chelagskai, in longitude $170^{\circ}$ E., along the Siberian coast as far as northern Kamschatka south to latitude $60^{\circ}$, also on some of the islands in the Bering Sea, and on the opposite coast of Alaska south to about latitude $55^{\circ}$ and eastward to Point Barrow. Herc again a long gap along the Arctic coast of North America, from Point Barrow in longitude $158^{\circ} \mathrm{W}$. to the western shore of Hudson Bay in longitude $97^{\circ} \mathrm{W}$., separates the Pacific from the Atlantic Walrus.

Southward the Atlantic Walrus ranged in earlier days even to the latitude of the British Isles, where they are extremely rarely seen to-day. The animal was apparently well known on northern European coasts in the latter part of the ninth century, and a century later was hunted on the coast of Finmark - one recalls how the Viking sea-captain Ochtherc related to King Alfred his voyage beyond the North Cape, where

$$
\begin{aligned}
& \text { "we hunted the walrus, } \\
& \text { The narwhal and the seal." }
\end{aligned}
$$

By 1600 WaIrus-hunting had become a regular trade; the animals were abundant on many of the islands off the Arctic coasts of Europe, and even on parts of the mainland coast. The establishment of trade with Russia, and the formation of the Muscovy Company, opened up for English seamen a wide ficld of exploitation in the far north. In 1616, for example, the company sent eight ships and two pinnaces to Spitsbergen under Thomas Edge. They arrived about 14th June, and as stated in Purchas, "imployed this yeere a small pinnasse unto the eastward, which discovered the eastward part of Greenland " (i.e. Spitsbergen), "namely the Iland now called Edges Iland, and other Ilands lying to the northwards as farre as $78^{\circ}$; this pinnasse was some 20 tunnes and had twelve men in her, who killed 1,000 sea-horses on Edges Iland, and brought all their teeth home for London." In 1617 the captain of a small ship, the John Ellis, obtained about 800 Walrus and brought back his ship with "the teeth and 30 tunnes of hides and the rest of his lading in oyle. He brought some sea-horse blubber with him ". It was, of course, not only English sailors who carried on the trade in Walrus; about 1640 a whaler named Ryke Yse, pursuing his business to the eastward, discovered the islands that still bear his name; and "found on them an incredible number of walruses and killed many hundred of them, 
so that, besides the blubber, he brought away an incredible wealth of tusks, and his owners sold them so well that they made a bigger profit than anyone ever heard of from such a voyage".

For centuries the tale was the same; near South Cape " in 1818 the winterers slew no less than 1,200 walruses besides quantities of other beasts, an unusually successful voyage".

On the Bear Islands, south of Spitsbergen and about 280 miles north of the North Cape, the captain of a ship belonging to the Muscovy Company accounted in 1611 for about 200 Walrus ; just when they had finished skinning and flensing them, an operation that took eleven days, the crew of the other ship of their outfit arrived in boats, their ship having foundered at Whales Bay where they had been compelled to leave on shore the blubber of some 500 Walrus they had killed. Half a century later (in 1667) 900 Walrus are stated to have been killed on the Bear Islands in less than seven hours.

It is not surprising that in modern times the Walrus had become so rare in these regions that in Spitsbergen their capture was prohibited for a period of ten years, commencing in 1926 .

On the American shores of the Atlantic the story has been much the same. On the eastern coast of North America, Walrus in the early colonial days occurred in numbers as far south as the Gulf of St. Lawrence and Cape Breton Island, and even on Sable Island off southern Nova Scotia.

In Hakluyt's Voyages we read how " the ship called the Marigold of 70 tunnes in burthen furnished with 20 men, whereof . . . 2 butchers to flea the Morsses or sea Oxen (whereof divers have teeth above a cubit long \& skinnes farre thicker than any buls hide)... departed out of Falmouth the 1 of June 1593 in consort of another ship of M. Drakes of Apsham . . which . . . was not ready so soone as shee should have bene by two moneths . . . for . . . an Island within the Streightes of Saint Peter on the backe side of Newfoundland to the Southwest in the latitude of fortie seven degrees, called by the Briton of Saint Malo the Isle of Ramea ... On which isle are so great abundance of the huge and mightie Sea Oxen with great teeth in the moneths of April, May, and June, that there have bene fifteene hundreth killed there by one small barke in the yeere $1591 "$.

About 1534 they were abundant on the Magdalen Islands in the Gulf of St. Lawrence, and many expeditions were fitted out in Europe for the capture of Walrus on these and neighbouring islands; heaps of Walrus-bones on the shores of the Magdalen 
Islands are said to have still been visible until about sixty years ago as reminders of the great slaughter that went on there. As late as the middle of the seventeenth century the Walrus regularly resorted for breeding purposes to Sable Island, which was apparently their most southern outpost when America was discovered; and they resorted there in dwindling numbers until exterminated. In 1635 two vessels set out from Boston for Sable Island "for sea-horse (which are there in great numbers)"; in 1639 a vessel was again reported as returning from Sable Island with sea-horse teeth, ete. ; in 1641 a Boston ship brought back 400 pairs of sea-horse teeth, 12 tons of oil, and many skins. After this date there is no evidence of expeditions; the French had also been killing the Walrus and it was no doubt becoming scarce. In 1753, when the island was advertised for sale, no mention was made of Walrus, which by then had probably been extinct for a considerable time.

At the present day the Walrus is stated to be only of casual occurrence even on the east coast of Labrador, though numbers still occur in Hudson Strait and the west part of Hudson Bay in times of open water.

The Pacific Walrus has not fared any better than its Atlantic relative. Though known to Europeans since the middle of the seventeenth century, and harried to some extent by Russian hunters even before 1800 , these animals were not greatly molested until about 1860 , when whaling had become less profitable than formerly. The animals had, of course, long been subjected to a limited amount of persecution, by the Eskimos on the Alaskan side and the Chukchis on the Siberian side of the Bering Sea, the coastal tribes of the latter in particular finding in the Walrus their chief means of subsistence. But it was not until the Americans with their far more deadly weapons came on the scene that the Walrus population began to decline. In this region during the period 1870-1880, American hunters accounted for about 100,000 Walrus, which yielded $1,996,000$ gallons of oil and $398,868 \mathrm{lb}$. of ivory; this in addition to the normal killing by the natives. During this decade the animals are belicved to have decreased by fifty per cent, and the pursuit still continued until it was no longer profitable.

At the present time the Pacific Walrus is stated to be restricted to a comparatively small area on the northern coasts of Siberia and Alaska, and one or two islands in the Bering Sea such as Walrus Island-(belonging to the Pribiloff group) and Hall Island (the westernmost of the St. Matthew group). The exploitation of the Pribiloff Islands fauna by the Russians is of long 
standing-as far back as 1805 a Russian writer stated that in a single year $28,000 \mathrm{lb}$. of Walrus ivory had been obtained there ; a statement which, though probably an exaggeration, indicates that the destruction of the Walrus was even then being actively pursued. At that time the animals occurred on both St. Paul's and St. George's Islands in the Pribiloff group, but later retreated to Walrus Island and its islets.

On the Alaskan mainland the Eskimos have apparently continued until recent years the destruction of the Walrus, the more effectively because of their being possessed of modern firearms. Bernard, discussing the position in 1923, wrote that whereas thirty or forty years previously great herds landed on the Alaskan coasts, now the remaining herds pass along the coast on their migration route but very few come ashore. The Eskimos therefore go out and hunt them on the ice, seldom succeding in bringing back more than the tusks, though to them the meat is of the greatest value. On a stretch of about 200 miles of coast near Point Barrow, Bernard saw over a thousand bodies of Walrus which had been killed among the ice floes by the Eskimos ; about one-third of these still had their tusks, indicating that they had been shot and had slipped off the ice and sunk before the hunters had reached them. He estimated that many thousands more must have been carried by the ice and currents northward into the Arctic Ocean. As a contrast to this, Bernard has described elsewhere how the Chukchis of a village on the Sibcrian coast had learned by necessity to adopt conservation measures, allowing the herd that came ashore a large amount of freedom from persceution, and killing only a limited number, with the result that increasing numbers of Walrus were landing on that strip of the Siberian coast.

Chilf Referhaces ror Modern Status

ALLEN, G. M. " Extinct and Vanishing MammaIs of the Western Hemisphere." (Publication of the American Committee for International Wildlife Protection, 1942), pp. 469-47\%.

Bernard, J. F. Journal of Mammalogy, vol. iv (1923), pp. 224-7, and vol. vi (1925), pp. 100-2.

Hanna, G. D. Ibid. (1923), pp. 209-220.

Henimiron, J., and Craig, E. I. "Economic Mammalogy," 1932, pp. 245-6, etc. 
KAFUE NATIONAL PARK, NORTHERN RHODESIA

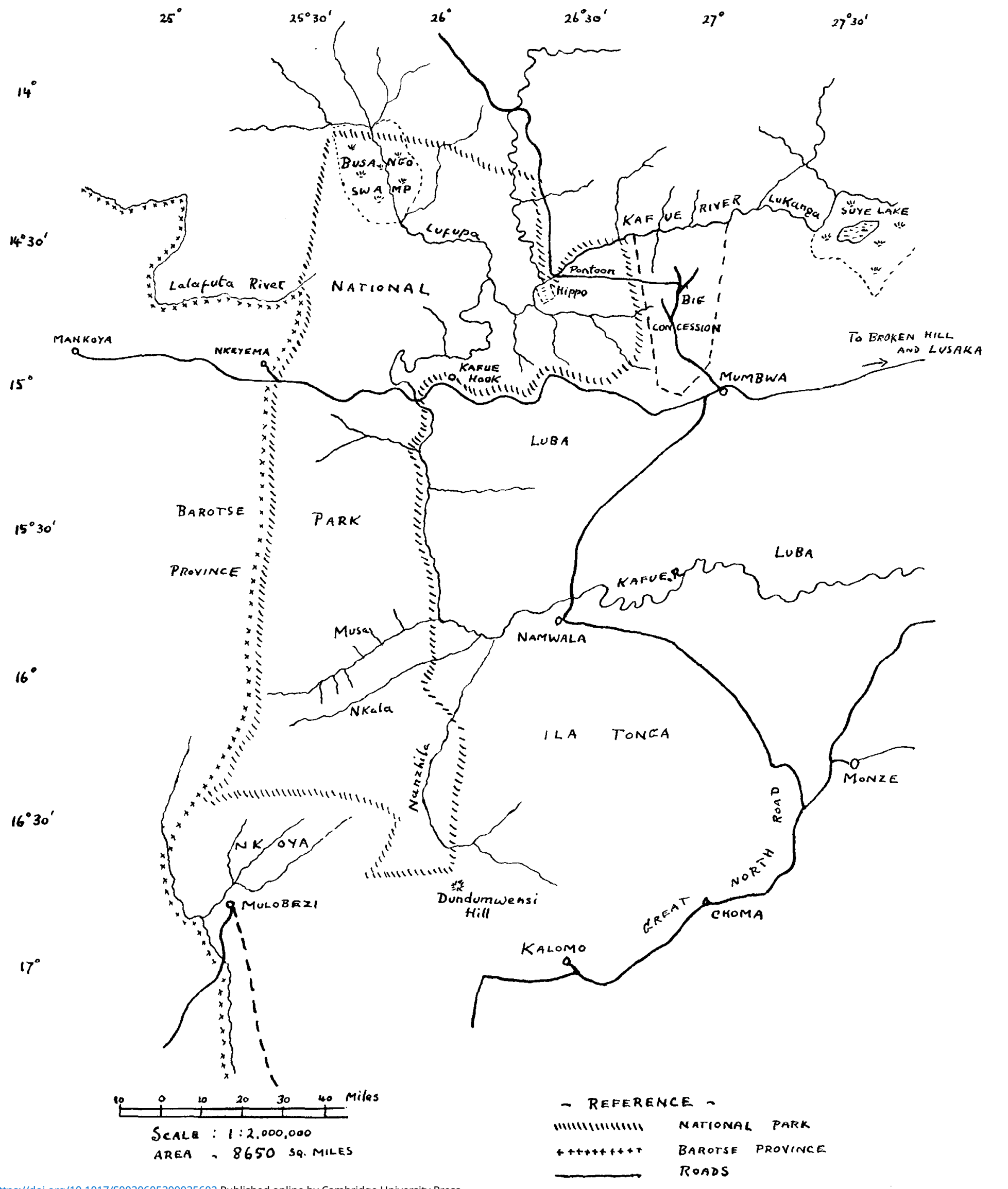

